\title{
Original paper \\ Source compositions and melting temperatures of the main granitic suites from the Moldanubian Batholith
}

\author{
Miloš RENÉ
}

Institute of Rock Structure and Mechanics, Academy of Sciences of the Czech Republic, V Holešovičkách 41, 182 09 Prague 8, Czech Republic; rene@irsm.cas.cz

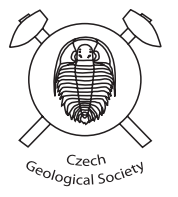

\begin{abstract}
The granitoids of the Moldanubian Batholith (Moldanubian Zone of the Bohemian Massif) are represented by three main suites: I- to I/S-type Weinsberg biotite granites-granodiorites, S-type Eisgarn two-mica granites and I/S-type Freistadt biotite granites-granodiorites. As shown by major-element data and zircon with monazite saturation thermometry, partial melting of metapelites likely produced most of the Eisgarn suite (Mrákotín/Číměř varieties) at $c .775-825^{\circ} \mathrm{C}$. Parental melts of the Weinsberg and Freistadt suites could have been generated by partial melting of a metagreywackes-metabasalts mixture at $c .740-940^{\circ} \mathrm{C}$.

This study confirms that the $\mathrm{CaO} / \mathrm{Na}_{2} \mathrm{O}$ ratio could be used for source assignment of S-type granite melts, whereas the $\mathrm{CaO} /\left(\mathrm{FeO}+\mathrm{MgO}+\mathrm{TiO}_{2}\right)$ ratio is more suitable for I/S-type granites. The observed systematic positive shift of $\mathrm{Al}_{2} \mathrm{O}_{3} /$ $\mathrm{TiO}_{2}$ temperatures compared with zircon and monazite saturation temperatures in all granitoids of the Moldanubian Batholith (up to $118{ }^{\circ} \mathrm{C}$ ) may be explained by accumulation of ilmenite in the S-type Eisgarn suite. In the I- and I/S-granite types of the Weinsberg and Freistadt suites the $\mathrm{Al}_{2} \mathrm{O}_{3} / \mathrm{TiO}_{2}$ ratio is controlled by the accumulation of ilmenite and/or titanite. Consequently, the $\mathrm{Al}_{2} \mathrm{O}_{3} / \mathrm{TiO}_{2}$ ratio may be used as a thermometer only with caution.
\end{abstract}

Keywords: granites, petrology, geochemistry, Moldanubian Zone, Bohemian Massif

Received: 12 April, 2016; accepted: 3 January, 2017; handling editor: J. Žák

The online version of this article (doi: 10.3190/jgeosci.223) contains supplementary electronic material.

\section{Introduction}

Low-pressure-high-temperature (LP-HT) metamorphism, crustal anatexis, and generation of granitic magmas are characteristic late-stage features in the development of collisional orogens (Le Fort et al. 1987; Guillot and Le Fort 1995; Williamson et al. 1996; Clemens 2003; Chappell and Hine 2006). One of the classic examples is the Variscan Belt in Europe, produced as a result of the late Palaeozoic convergence of Gondwana and Laurussia. The Moldanubian Batholith (MB) that forms one of the largest plutonic complexes within the European Variscan Belt, covering $10000 \mathrm{~km}^{2}$ in the central and western parts of the Moldanubian Zone of Bohemian Massif (an easterly exposure of the European Variscan Belt), provides an excellent insight into the origin and emplacement of such crustally derived magmas (e.g., Liew et al. 1989; Holub et al. 1995; Gerdes et al. 2000; Finger et al. 2009; Verner et al. 2014).

The aim of this paper is to estimate the source composition of the $\mathrm{MB}$ from major-element ratios, especially $\mathrm{CaO} / \mathrm{Na}_{2} \mathrm{O}, \mathrm{Al}_{2} \mathrm{O}_{3} / \mathrm{TiO}_{2}$ and $\mathrm{CaO} /\left(\mathrm{FeO}+\mathrm{MgO}+\mathrm{TiO}_{2}\right)$. Melting temperature estimations are based on $\mathrm{Al}_{2} \mathrm{O}_{3} /$ $\mathrm{TiO}_{2}$ thermometry (after Jung and Pfänder 2007) and on more conventional zircon and monazite saturation thermometry (Watson 1979; Watson and Harrison 1983; Montel 1993). Partial melting of metapelites produced the majority of the Eisgarn suite at temperatures ranging from 770 to $830^{\circ} \mathrm{C}$. Melts of the Weinsberg and Freistadt suites were generated by partial melting of a mixture of metagreywackes and metabasalts at temperatures in the range of $740-940^{\circ} \mathrm{C}$.

\section{Geological setting}

In map-view, the MB consists of two-nearly perpendicular segments (Fig. 1). The first, NNE-SSW trending segment, is formed mainly by a large continuous exposure of plutonic rocks, whereas the $\sim \mathrm{NW}-\mathrm{SE}$ segment is defined by a number of separate smaller plutons, some of which seem to be either roughly parallel to, or are crosscut by, the $\sim \mathrm{NW}-\mathrm{SE}$ trending regional Pfahl and Danube shear zones (Brandmayr et al. 1995, 1999; Mattern 2001; Büttner 2007). Both batholith segments are closely associated with the host migmatites.

In more detail, the MB is built by multiple plutons and stocks, predominantly composed of granitic to granodioritic rocks with either S- or transitional I/S-type character (e.g., Holub et al. 1995; Gerdes et al. 2000; Finger et al. 1997, 2009; Breiter and Koller 1999; René et al. 2008; Breiter 2010). All these granitoids can be classified into several, in part diachronous, main suites. The most important are coarse-grained, porphyritic I- to I/S-type 


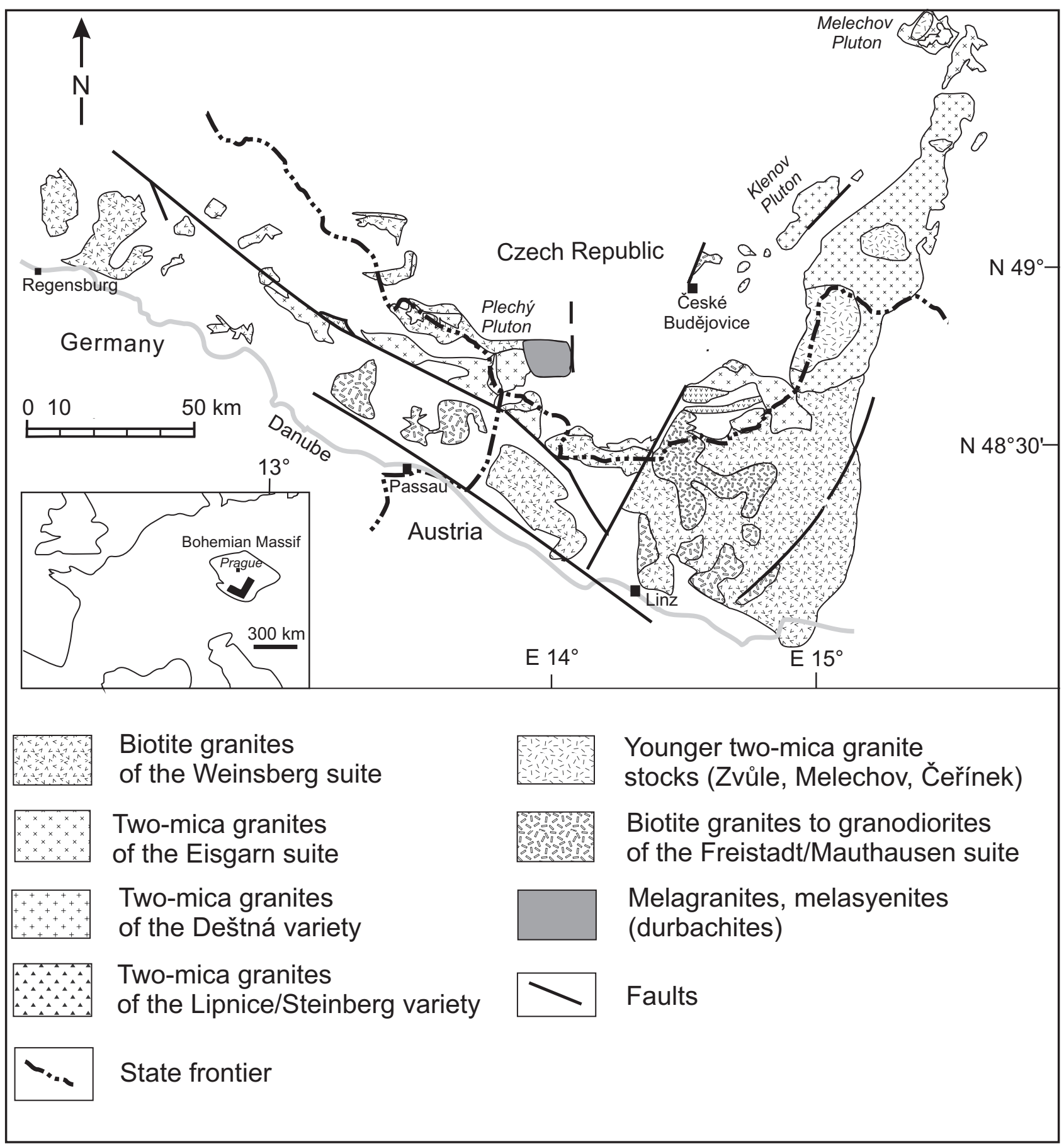

Fig. 1 Simplified geological map of the Moldanubian Batholith showing distribution of main granite suites (after Verner et al. 2015, modified).

biotite granites-granodiorites of the Weinsberg suite (331-323 Ma), S-type two-mica granites of the Eisgarn suite (329-324 Ma), and fine- to medium-grained I/S-type biotite granites-granodiorites of the Freistadt/Mauthausen suite (320-310 Ma). The Rastenberg and Knížecí Stolec plutons (337-340 Ma) are part of the durbachitic granites belt; also different diorites form small isolated bodies (323-327 Ma) within the Moldanubian Batholith (e.g., Gebharts diorites) (Frasl and Finger 1988; Liew et al. 1989; Vellmer and Wedepohl 1994; Klötzli and Parrish 1996; Finger et al. 1997, 2009; Gerdes et al. 2000, 2003; Siebel et al. 2008; Žák et al. 2011; Verner et al. 2008, 2014).

The Weinsberg suite (WbG) represents coarse-grained biotite granites to granodiorites. Previous systematic studies of zircon morphology (Stöbich 1992) identified two main WbG varieties: coarse-grained, porphyritic biotite granites to granodiorites (Weinsberg I) and very 
coarse-grained, porphyritic biotite to muscovite-biotite granites (Weinsberg II) (Frasl and Finger 1988; Liew et al. 1989; Gerdes 2001).

The two-mica granites of the MB are commonly referred to as the Eisgarn suite, first defined near the village of Eisgarn in Austria (Köhler 1931) and later described as the Číměr variety in the Czech part of the MB (Zoubek 1949). Both granite varieties are represented by porphyritic monzogranite with predominance of biotite over muscovite. Several equigranular varieties were also identified (Mrákotín - Koutek 1925; Sulzberg - Fuchs 1964; Haidmühle, Theresienreut - Ott 1988). In the Klenov Pluton, the leucocratic Deštná granite occurs (Klečka et al. 1991; René et al. 2008). In the Eisgarn granite suite are intruded dykes of microdiorites - microgranodiorites, granite porphyries, dyke rhyolites and small stocks of highly fractionated muscovite granites (e.g., Homolka stock) (René 2003, Breiter 2010 and references therein).

Two significant petrographic varieties were previously identified in the main body of the Freistadt suite in the Austrian Mühlviertel, the coarse-grained, biotite granodiorites of the "marginal variety" and medium-grained, biotite granodiorites of the "central variety" (Klob 1971). Later, in the area of Freistadt, the muscovite-bearing biotite granites were recognised by Friedl (1990) and described as the Grabengranite variety.

\section{Analytical methods}

Rock samples of $2-5 \mathrm{~kg}$ in weight were crushed in a jaw crusher and a representative split of this material was ground in an agate ball mill. Major elements and some trace elements ( $\mathrm{Ba}, \mathrm{Rb}, \mathrm{Sr}, \mathrm{Zr}, \mathrm{Nb}, \mathrm{Y}, \mathrm{U}, \mathrm{Th})$ were determined using a Bruker AXS S4 Pioneer X-ray fluorescence (XRF) spectrometer at the University of Salzburg, Austria on fused glass discs and pressed rock powder pellets, respectively. The $\mathrm{FeO}$ was determined by titration and $\mathrm{H}_{2} \mathrm{O}^{+}$and $\mathrm{H}_{2} \mathrm{O}^{-}$were analysed gravimetrically in the chemical laboratory of the Institute of Rock Structure and Mechanics, Czech Academy of Sciences in Prague. Rare earth elements (REE) were quantified by inductive coupled plasma mass spectrometry (ICP-MS) techniques at Activation Laboratories Ltd., Ancaster, Canada, using a Perkin Elmer Sciex ELAN 6100 ICP mass spectrometer, following standard lithium metaborate/tetraborate fusion and acid decomposition sample preparation procedures (4B2-Research, http:// www.actlabs.com). Zircon and monazite saturation temperatures were calculated using the GCDkit 4.1 software (Janoušek et al. 2016).

Microprobe analyses of selected minerals (feldspars, biotite) were performed in polished thin sections

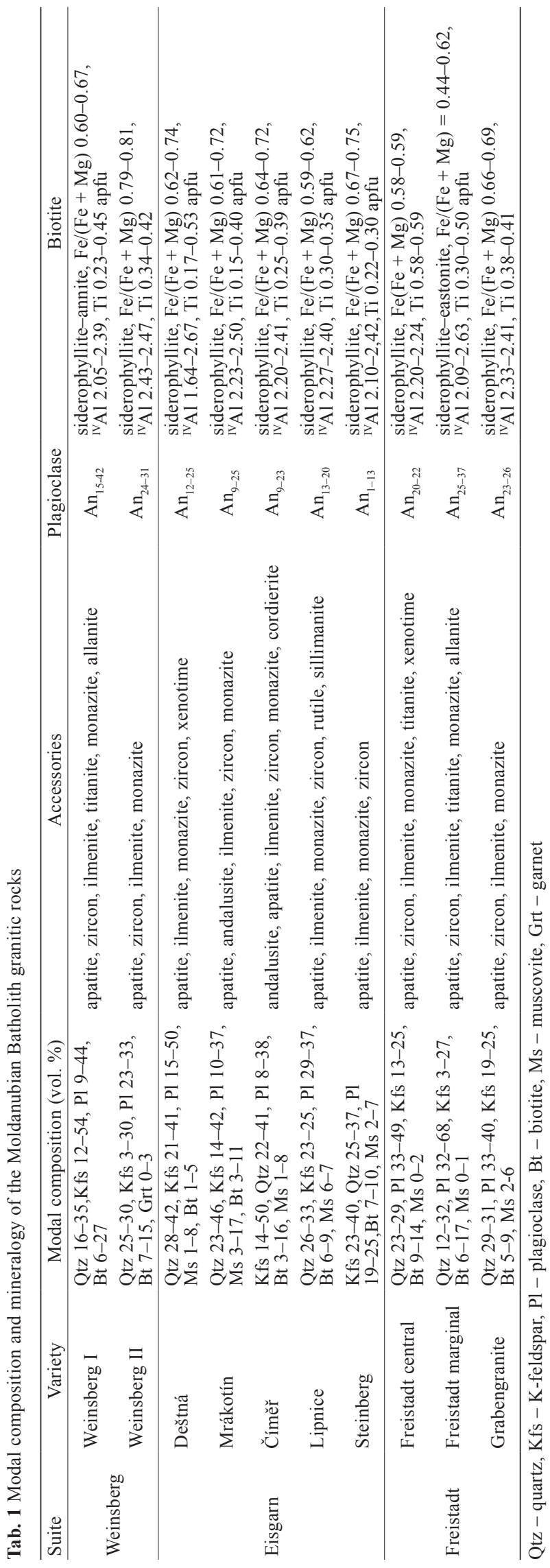



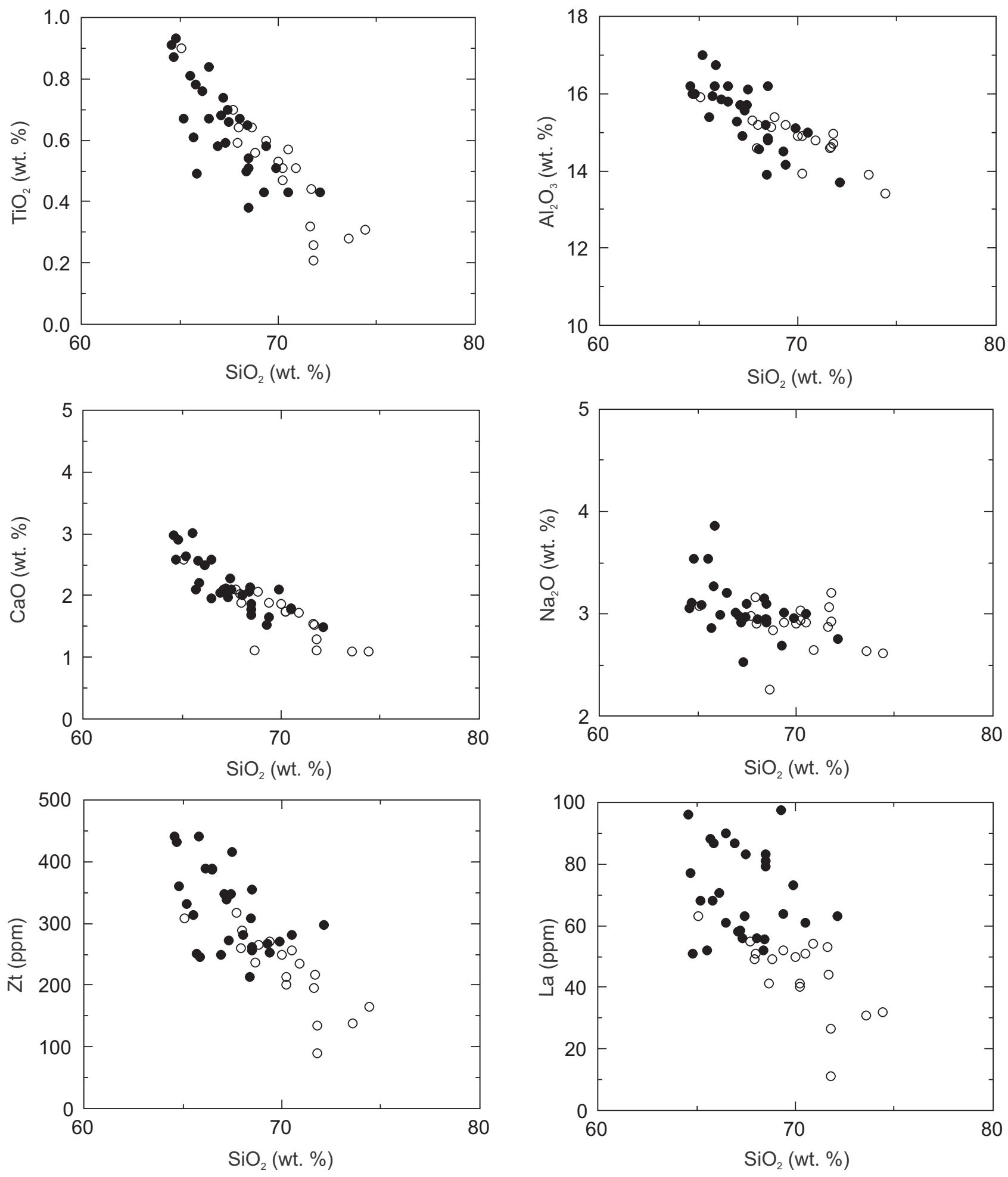

- Weinsberg I O Weinsberg II

Fig. 2 Binary plots of $\mathrm{TiO}_{2}, \mathrm{Al}_{2} \mathrm{O}_{3}, \mathrm{CaO}, \mathrm{Na}_{2} \mathrm{O}, \mathrm{Zr}$ and $\mathrm{La}$ vs. $\mathrm{SiO}_{2}$ for granitic rocks of the Weinsberg suite.

using a CAMECA SX-100 microprobe operated in wavelength-dispersive mode at the Institute of Geol- ogy, Czech Academy of Sciences, Prague. The raw analytical data were corrected using the PAP procedure 

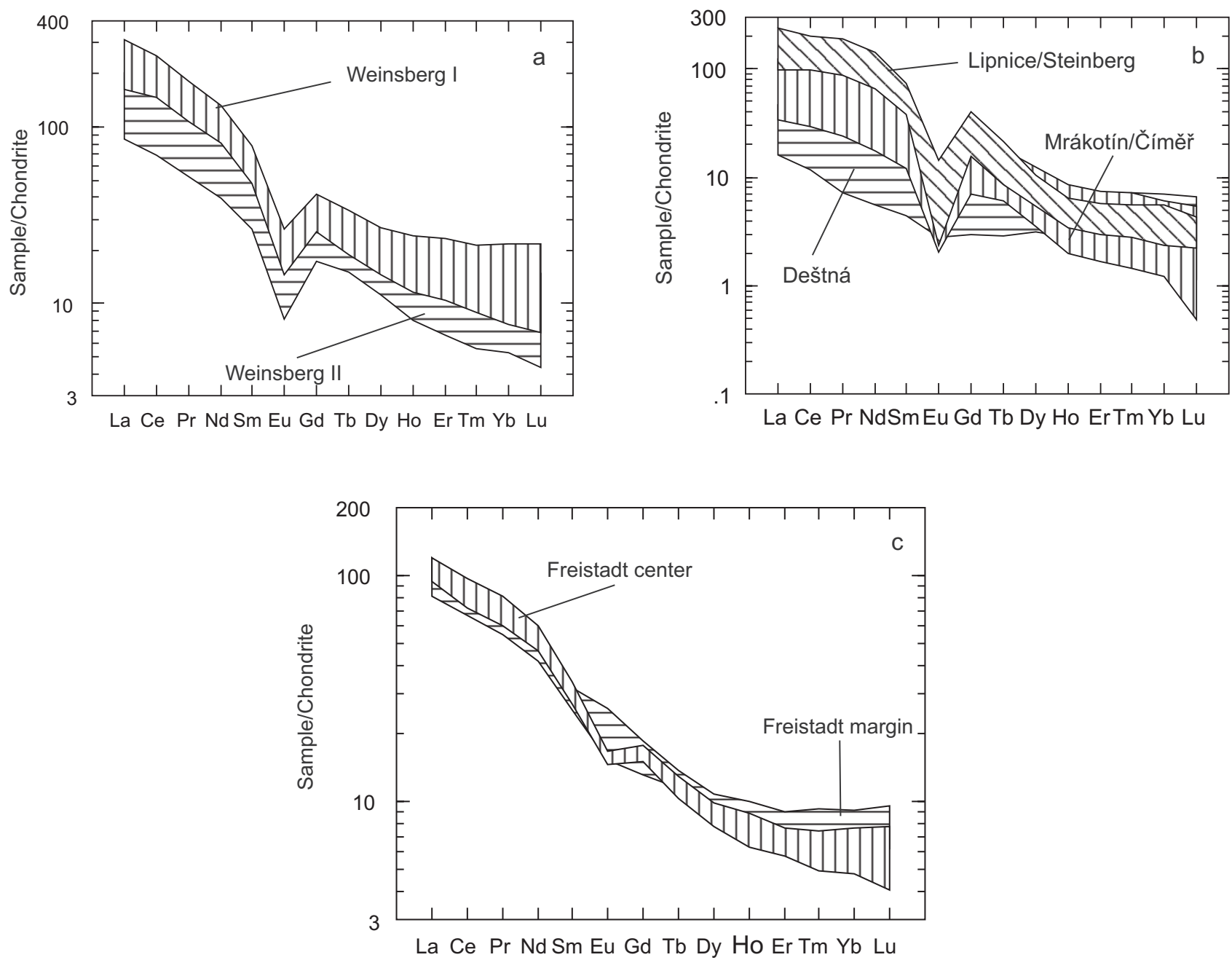

Fig. 3 Chondrite-normalized REE patterns for granitic rocks of the Weinsberg suite (a), Eisgarn suite (b) and Freistadt suite (c). Normalizing values are from Boynton (1984).

(Pouchou and Pichoir 1985). Operation conditions were: accelerating potential $15-20 \mathrm{kV}$, beam current $10-70 \mathrm{nA}$ (measured on a Faraday cup) and a beam diameter of $2 \mu \mathrm{m}$. Both synthetic and natural minerals were used as reference materials. Mineral formulae were recalculated using the MinPet 2.02 software (Richard 1995).

\section{Results}

\subsection{Petrography}

The Weinsberg suite represents coarse-grained, biotite granites to granodiorites with megacrystic K-feldspar. Major components of the Weinsberg granite are quartz,

Tab. 2 Chemical composition of Moldanubian Batholith granitic rocks

\begin{tabular}{|c|c|c|c|c|c|c|c|c|c|c|c|}
\hline Suite & Variety & $\mathrm{A} / \mathrm{CNK}$ & $\mathrm{SiO}_{2}$ wt. $\%$ & $\mathrm{TiO}_{2}$ wt. $\%$ & $\mathrm{Al}_{2} \mathrm{O}_{3}$ wt.\% & $\mathrm{CaO}$ wt.\% & Zr ppm & Th ppm & $\mathrm{Rb}$ ppm & $\mathrm{La}_{\mathrm{N}} / \mathrm{Yb}_{\mathrm{N}}$ & $\mathrm{Eu} / \mathrm{Eu}^{*}$ \\
\hline \multirow{2}{*}{ Weinsberg } & Weinsberg I & $1.0-1.1$ & $64.6-72.1$ & $0.4-0.9$ & $13.7-17.0$ & $1.5-3.0$ & $214-441$ & $19-45$ & $157-279$ & $10.0-33.4$ & $0.30-0.60$ \\
\hline & Weinsberg II & $1.1-1.4$ & $65.1-74.0$ & $0.2-0.9$ & $13.4-15.9$ & $1.1-2.6$ & 89-389 & $4-69$ & $172-304$ & $9.7-19.0$ & $0.28-0.53$ \\
\hline \multirow{5}{*}{ Eisgarn } & Deštná & $1.0-1.2$ & $72.0-74.4$ & $0.1-0.2$ & $13.7-15.4$ & $0.5-1.2$ & $15-94$ & $2-7$ & $154-265$ & $3.2-15.6$ & $0.96-1.18$ \\
\hline & Mrákotín & $1.1-1.3$ & $70.6-74.3$ & $0.1-0.4$ & $13.6-15.3$ & $0.4-1.1$ & $75-175$ & $8-37$ & $181-393$ & $7.1-47.9$ & $0.15-0.59$ \\
\hline & Číměř & $1.1-1.3$ & $70.8-74.7$ & $0.2-0.4$ & $13.5-16.0$ & $0.5-1.1$ & $84-175$ & $23-54$ & $236-450$ & $13.5-43.3$ & $0.16-0.37$ \\
\hline & Lipnice & $1.1-1.3$ & $69.5-71.4$ & $0.4-0.5$ & $14.5-15.7$ & $0.9-1.1$ & $182-291$ & $39-54$ & $321-363$ & $29.4-39.0$ & $0.24-0.31$ \\
\hline & Steinberg & $1.2-1.4$ & $70.3-75.5$ & $0.3-0.5$ & $13.0-15.0$ & $0.3-0.9$ & $143-251$ & $55-110$ & $380-521$ & $20.0-64.5$ & $0.09-0.17$ \\
\hline \multirow{3}{*}{ Freistadt } & Freistadt central & $1.0-1.1$ & $68.1-69.1$ & $0.4-0.5$ & $16.0-16.3$ & $2.4-3.4$ & $102-164$ & $8-13$ & $74-90$ & $12.2-20.9$ & $0.68-0.81$ \\
\hline & Freistadt marginal & $1.0-1.1$ & $65.2-71.3$ & $0.3-0.7$ & $14.9-17.0$ & $2.0-4.1$ & $99-214$ & $7-18$ & $59-219$ & $9.9-16.6$ & $0.56-0.84$ \\
\hline & Grabengranite & $1.1-1.1$ & $69.9-72.9$ & $0.3-0.4$ & $14.8-15.8$ & $1.8-2.3$ & $98-171$ & $10-15$ & $85-112$ & $19.7-30.7$ & 0.58 \\
\hline
\end{tabular}



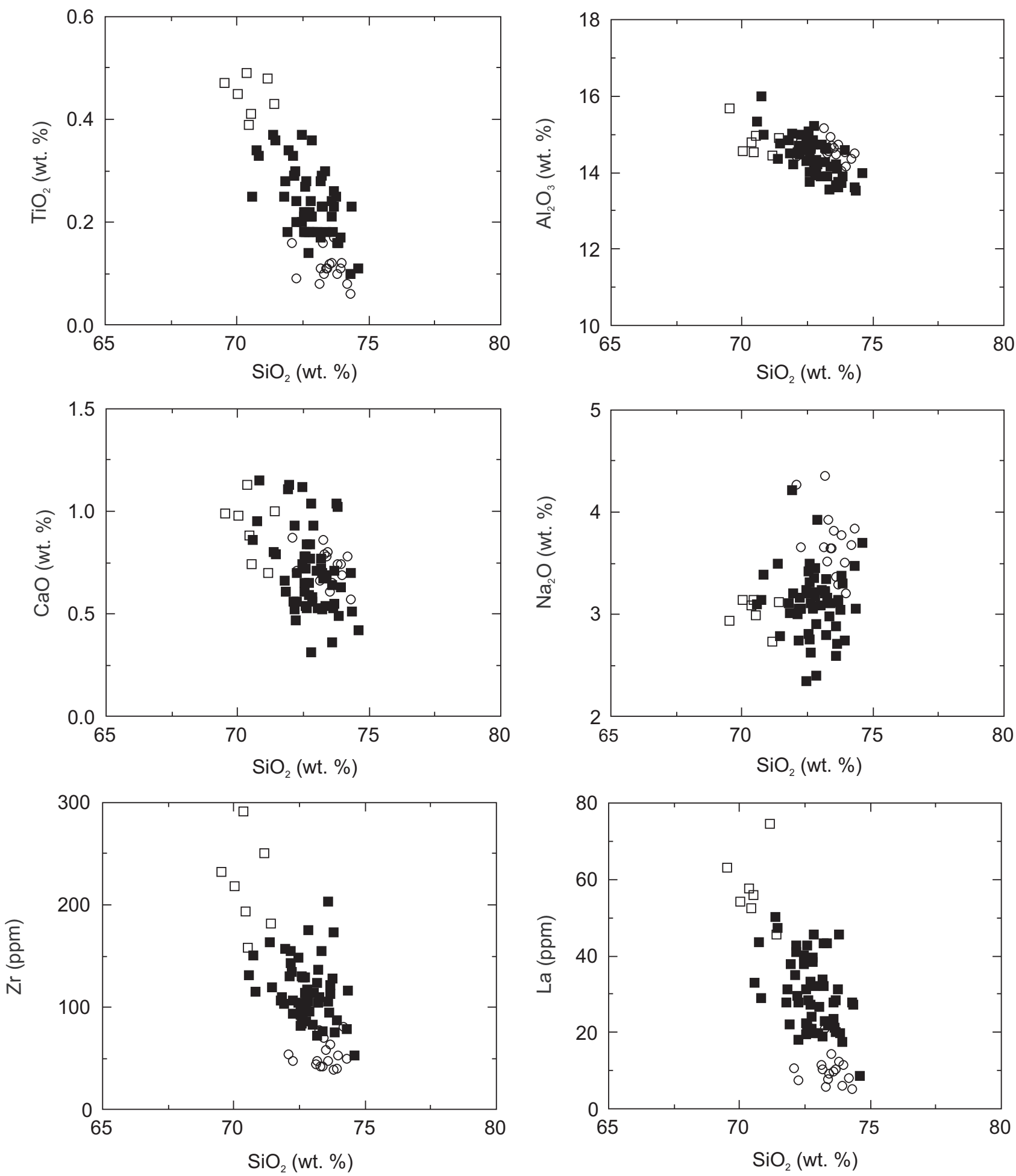

- Deštná granite - Mrákotín/Číměř granite $\square$ Lipnice/Steinberg granite

Fig. 4 Binary plots of $\mathrm{TiO}_{2}, \mathrm{Al}_{2} \mathrm{O}_{3}, \mathrm{CaO}, \mathrm{Na}_{2} \mathrm{O}, \mathrm{Zr}$ and $\mathrm{La}$ vs. $\mathrm{SiO}_{2}$ for granitic rocks of the Eisgarn suite.

K-feldspar, plagioclase and biotite. The accessories include apatite, zircon, ilmenite, titanite, allanite, monazite and very rare xenotime. For some samples of the Weinsberg II granite, the presence of garnet was observed (Tab. 1). 

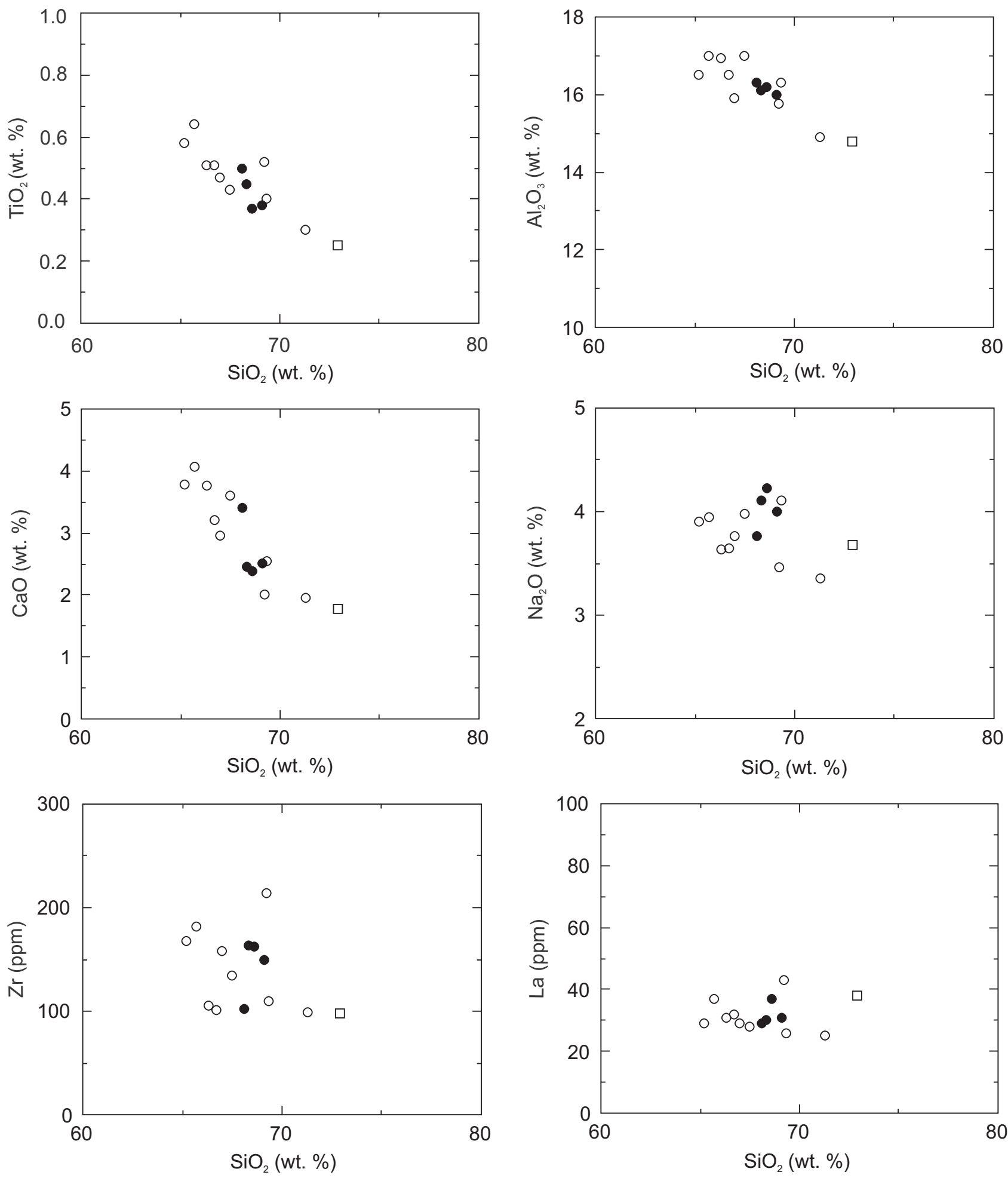

- Freistadt central $\bigcirc$ Freistadt marginal $\square$ Grabengranite

Fig. 5 Binary plots of $\mathrm{TiO}_{2}, \mathrm{Al}_{2} \mathrm{O}_{3}, \mathrm{CaO}, \mathrm{Na}_{2} \mathrm{O}, \mathrm{Zr}$ and $\mathrm{La}$ vs. $\mathrm{SiO}_{2}$, for granitic rocks of the Freistadt suite.

The two-mica granites of the Eisgarn suite are the most abundant granitic rocks in the MB. Several petro- graphic varieties were identified, with variable texture and biotite to muscovite proportions. Monzogranites 


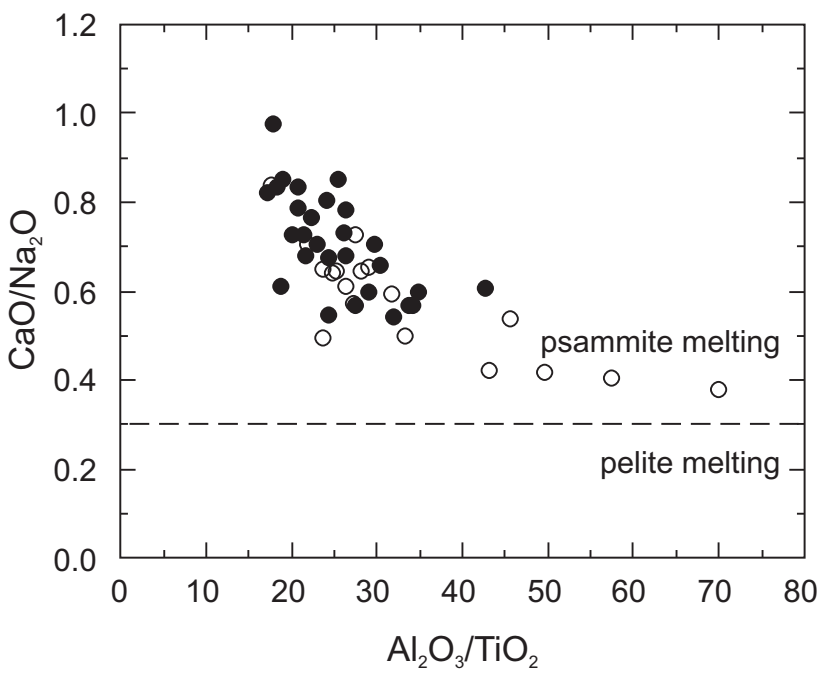

- Weinsberg I O Weinsberg II

Fig. 6 Plot of $\mathrm{CaO} / \mathrm{Na}_{2} \mathrm{O}$ vs. $\mathrm{Al}_{2} \mathrm{O}_{3}$ for granitic rocks of the Weinsberg suite with boundary between experimental melts derived from metapelitic and metapsammitic sources (Jung and Pfänder 2007).

dominate over alkali feldspar granites and granodiorites. The Eisgarn suite is generally represented by a porphyritic variety with biotite $>$ muscovite (Č́měř/Eisgarn). In the Czech part of the MB, the equigranular granite of the Mrákotín variety predominates. Similar equigranular two-mica granites occur in NW Austria (Sulzberg variety in the Aigen Pluton) and Bavaria (Haidmühle, Theresienreut). In the Klenov Pluton, the equigranular two-mica leucogranites are known as the Deštná granite. In the following section, all the equigranular granites are referred to as the Mrákotín variety (Tab. 1). Accessory minerals

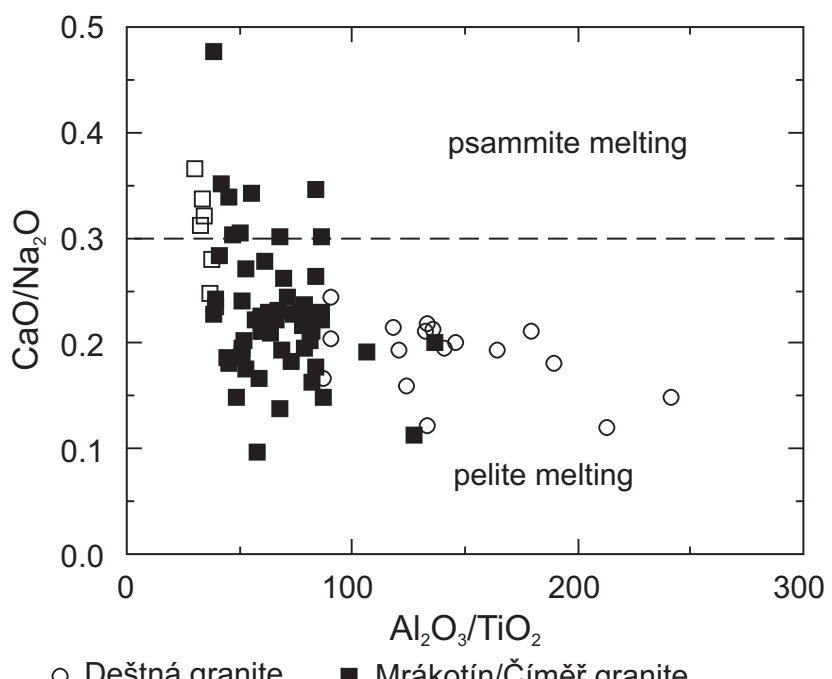

$\square$ Lipnice/Steinberg granite

Fig. 7 Plot of $\mathrm{CaO} / \mathrm{Na}_{2} \mathrm{O}$ vs. $\mathrm{Al}_{2} \mathrm{O}_{3}$ for granitic rocks of the Eisgarn suite with boundary between experimental melts derived from metapelitic and metapsammitic sources (Jung and Pfänder 2007).

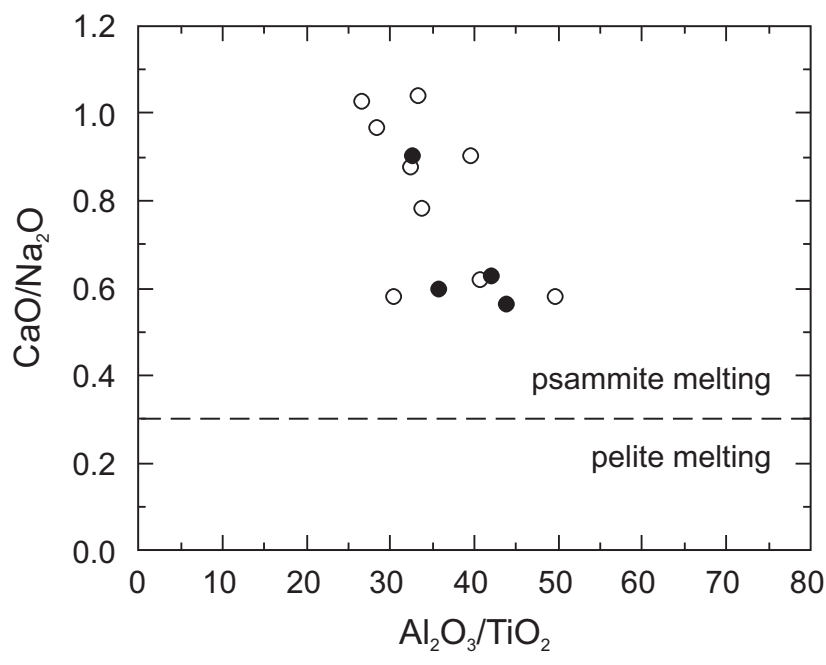

- Freistadt central $\bigcirc$ Freistadt marginal

Fig. 8 Plot of $\mathrm{CaO} / \mathrm{Na}_{2} \mathrm{O}$ vs. $\mathrm{Al}_{2} \mathrm{O}_{3}$ for granitic rocks of the Freistadt suite with boundary between experimental melts derived from metapelitic and metapsammitic sources (Jung and Pfänder 2007).

in the porphyritic and equigranular varieties of two-mica granites are apatite, ilmenite, zircon and monazite. The accessory mineral assemblage in the Deštná granite contains xenotime in addition.

Major rock-forming minerals of both varieties of the Freistadt biotite granodiorites are quartz, plagioclase, $\mathrm{K}$-feldspar and biotite. The Grabengranite contains 3-6 vol. \% of muscovite and a slightly lower amount of biotite. The accessories in the Freistadt granodiorite in-

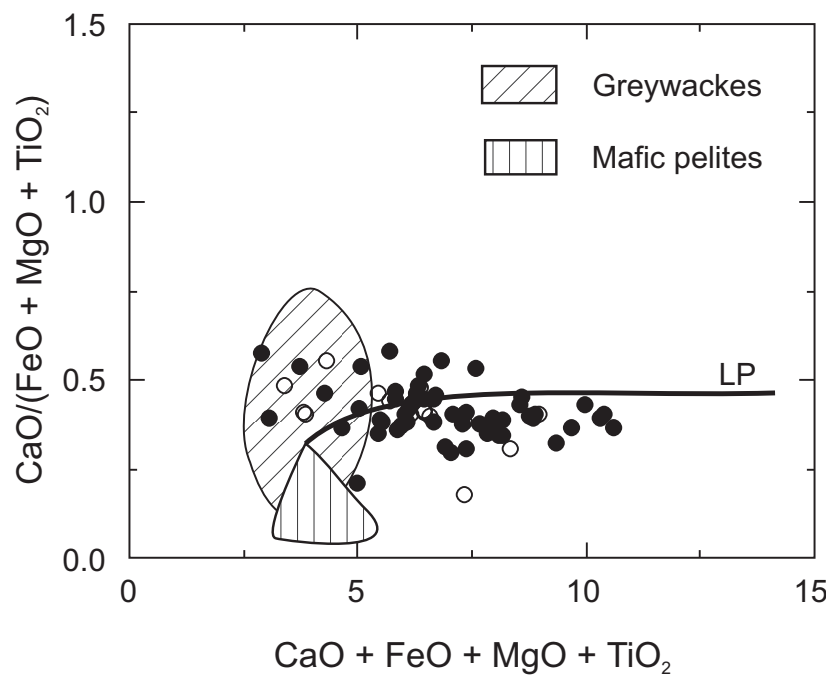

- Weinsberg I O Weinsberg II

Fig. 9 Composition of the Weinsberg suite compared to melts produced by experimental dehydration melting of various types of metasediments summarized by Patiño Douce (1999). The thick solid line 'LP' is reaction curve that would be produced by hybridization of high-Al tholeiite with metapelite at low pressure $(<5$ kbar) (Patiño Douce 1995, 1999). 


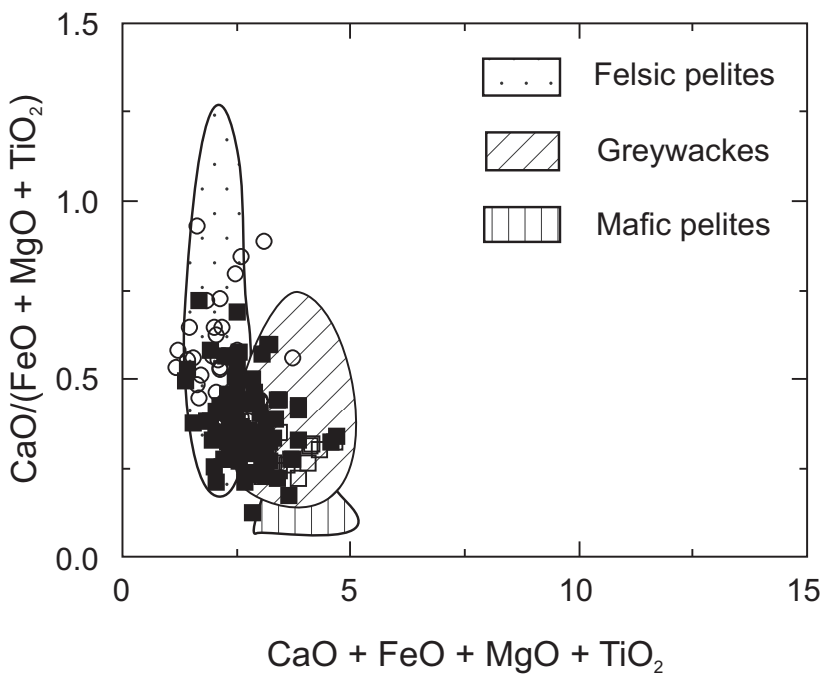

\section{○ Deštná granite घ Mrákotín/Číměř granite \\ $\square$ Lipnice/Steinberg granite}

Fig. 10 Composition of the Eisgarn suite compared to melts produced by experimental dehydration melting of various types of metasediments (after Patiño Douce 1999).

clude apatite, ilmenite, zircon, titanite, allanite and rare xenotime (Tab. 1).

\subsection{Geochemistry}

Discussion of the whole-rock composition of selected granitoids is based on the analyses of 66 samples, both new and published previously (René 2012, 2013; René and Hájek 2010, 2011; René et al. 2008). Their list and analyses are given in the electronic supplement. For the geochemical study of the Weinsberg and Freistadt suite, published analyses of Gerdes (1997) were also used.

The WbG I, II are subaluminous to weakly peraluminous granites with $\mathrm{A} / \mathrm{CNK}\left[\mathrm{mol} . \mathrm{Al}_{2} \mathrm{O}_{3} /\left(\mathrm{CaO}+\mathrm{Na}_{2} \mathrm{O}+\right.\right.$ $\left.\mathrm{K}_{2} \mathrm{O}\right)$ ] of $0.9-1.2, \mathrm{SiO}_{2} 65-74$ wt. \%, $\mathrm{Na}_{2} \mathrm{O} 2.3-3.9$ wt. \%, $\mathrm{K}_{2} \mathrm{O} 3.4-6.2$ (Fig. 2) and fractionated REE patterns $\left(\mathrm{La}_{\mathrm{N}} /\right.$ $\mathrm{Yb}_{\mathrm{N}}=9.7-33.4$; Fig. 3a). Of both varieties of the Weinsberg suite are characteristic high Ba (291-1038 ppm), Sr (75-251 ppm), Zr (89-441 ppm) and EREE (133-491 ppm). The WbG II differs from the WbG I by lower $\mathrm{Sr}$ (75-206 ppm) and lower $\mathrm{La}_{\mathrm{N}} / \mathrm{Yb}_{\mathrm{N}}$ ratios (9.7-19.0) (Fig. 3a, Tab. 2).

Three main geochemical varieties of two-mica granites could be distinguished: the low-Th (2-7 ppm) Deštná granites, the intermediate-Th Mrákotín/Č́měř granites (8-54 ppm) and the high-Th Lipnice/Steinberg granites (39-110 ppm) (Tab. 2). All these granites are subaluminous to strongly peraluminous (A/CNK 1.0-1.3) with low $\mathrm{CaO}$ concentrations (0.3-1.2 wt. \%) (Fig. 4, Tab. 2).

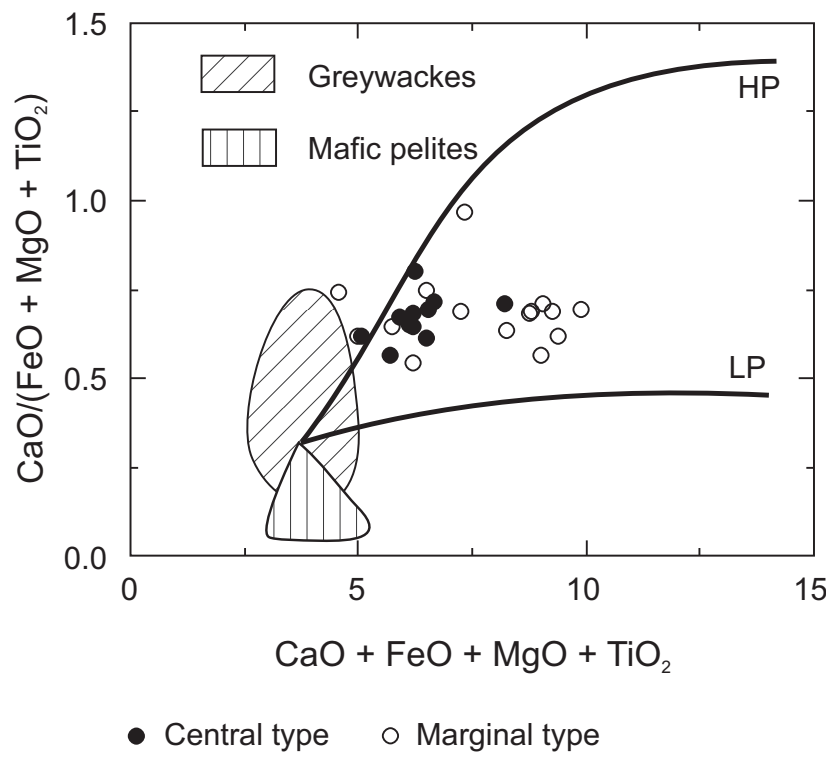

Fig. 11 Composition of the Freistadt suite compared to melts produced by experimental dehydration melting of various types of metasediments (Patiño Douce 1999). The thick solid lines are reaction curves that would be produced by hybridization of high-Al tholeiite with metapelite at low pressure (LP, < 5 kbar) and high pressure (HP, 12-15 kbar) (Patiño Douce 1995, 1999).

In the most peraluminous ones, magmatic andalusite, sillimanite and rarely cordierite are present. In Mrákotín granites, peraluminosity is also expressed by widespread dominance of muscovite over biotite. The highest $\Sigma$ REE was found in the Lipnice and Steinberg granites (207-242 ppm), whereas the lowest $\Sigma$ REE was observed in the Deštná granites (33-69 ppm). For granites of the Mrákotín/Číměř variety, higher LREE/HREE ratios $\left(\mathrm{La}_{\mathrm{N}} /\right.$ $\left.\mathrm{Yb}_{\mathrm{N}}=7-48\right)$ and, remarkably deep negative Eu anomalies $\left(\mathrm{Eu} / \mathrm{Eu}^{*}=0.15-0.59\right)$ were found. The decrease in LREE, $\mathrm{Th}$ and $\mathrm{Zr}$ with increasing $\mathrm{Rb}$ and $\mathrm{Cs}$ concentrations can be observed in more fractioned samples of these granites. The LREE/HREE ratio of the Lipnice/Steinberg varieties is higher $\left(\mathrm{La}_{\mathrm{N}} / \mathrm{Yb}_{\mathrm{N}}=20-65\right)$ than in the Deštná granites $\left(\mathrm{La}_{\mathrm{N}} / \mathrm{Yb}_{\mathrm{N}}=3-16\right)$. The Deštná granites display none or slightly positive Eu anomaly $\left(\mathrm{Eu} / \mathrm{Eu}^{*}=0.96-1.18\right)$ (Fig. 3b, Tab. 2).

All varieties of the Freistadt suite are subaluminous $(\mathrm{A} / \mathrm{CNK}=1.0-1.1)$ with elevated $\mathrm{CaO}$ concentrations (marginal granodiorites: 2.0-4.1 wt. \%, central granodiorites 2.4-3.4 wt. \%, Grabengranite: 1.8-2.3 wt. \%) (Fig. 5). Granodiorites of the central and marginal facies are rich in $\mathrm{Ba}$ (687-1017 ppm, 469-875 ppm) and $\mathrm{Sr}$ (316-334 ppm, 253-471 ppm) respectively; their $\Sigma$ REE are 129-279 ppm. These granodiorites display relatively low $\mathrm{La}_{\mathrm{N}} / \mathrm{Yb}_{\mathrm{N}}$ of $10-17$ with moderate to low negative $\mathrm{Eu}$ anomaly $\left(\mathrm{Eu} / \mathrm{Eu}^{*}=0.56-0.84\right)$ and low Th $(7-18 \mathrm{ppm})$. The Grabengranite is more fractioned with $\mathrm{La}_{\mathrm{N}} / \mathrm{Yb}_{\mathrm{N}}=20-31$ and $\mathrm{Eu} / \mathrm{Eu} *=0.58$ (Fig. 3c, Tab. 2). 

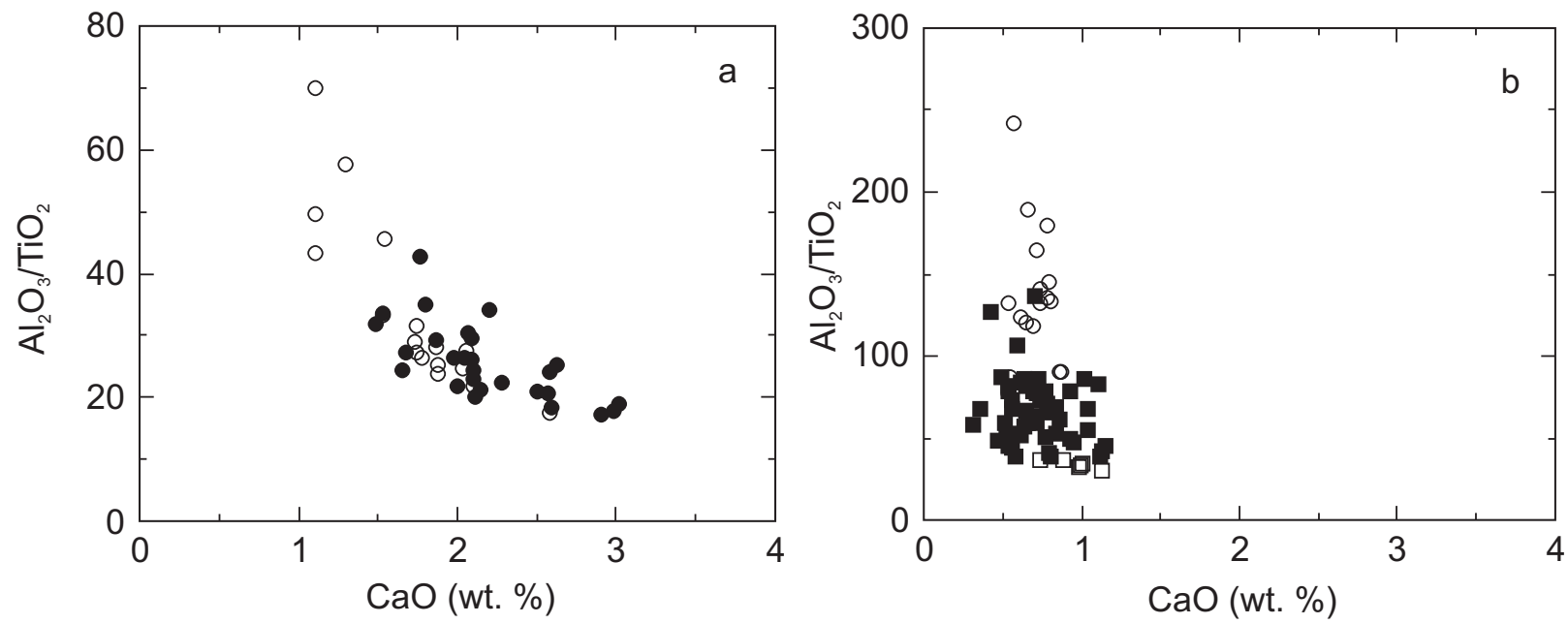

- Weinsberg I $\bigcirc$ Weinsberg II $\bigcirc$ Deštná granite - Mrákotín/Číměř granite

Lipnice/Steinberg granite

b

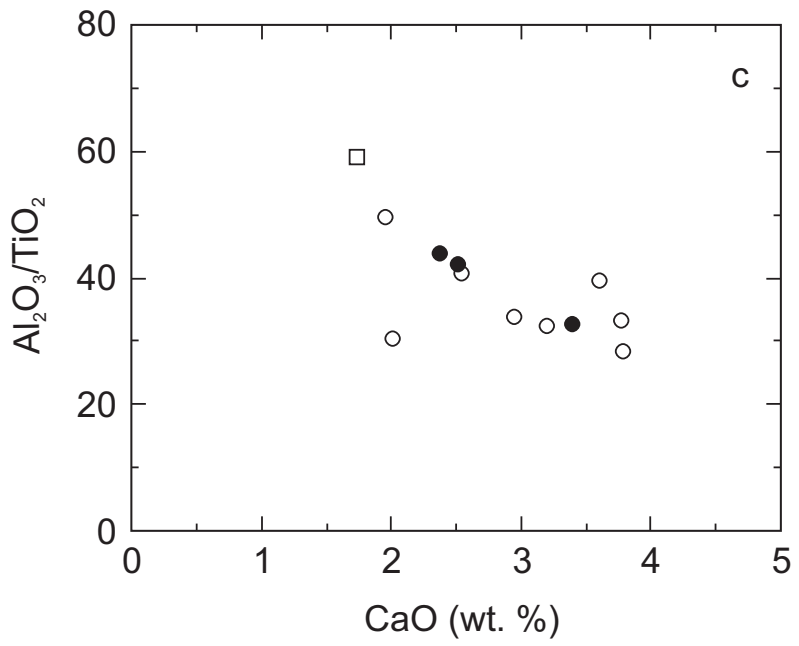

- Freistadt central $\bigcirc$ Freistadt marginal $\square$ Grabengranite

Fig. 12 Plot of $\mathrm{Al}_{2} \mathrm{O}_{3} / \mathrm{TiO}_{2}$ vs. $\mathrm{CaO}$ for granitic rocks of the Weinsberg suite (a), Eisgarn suite (b) and Freistadt suite (c).

\section{3. $\mathrm{CaO} / \mathrm{Na}_{2} \mathrm{O}$ as an index of source composition}

As shown by Sylvester (1998) and Jung and Pfänder (2007), the $\mathrm{CaO} / \mathrm{Na}_{2} \mathrm{O}$ ratio can be used to highlight the effect of source composition on granitic melts. For highly peraluminous granites with clay-rich sources, the $\mathrm{CaO}$ / $\mathrm{Na}_{2} \mathrm{O}$ ratio is a valuable index of source composition. However, it is less useful for intermediate I/S type rocks, as their $\mathrm{CaO} / \mathrm{Na}_{2} \mathrm{O}$ ratios are similar to those of metagreywackes (e.g., Condie 1993; Sylvester 1998). Partial melts of metapelites have $\mathrm{CaO} / \mathrm{Na}_{2} \mathrm{O}<0.3$, whereas those of metagreywackes have this ratio mostly higher. Melts with variable, and often high $\mathrm{CaO} / \mathrm{Na}_{2} \mathrm{O}$ ratios of 0.1 to 9.9 may be derived from metabasaltic sources, as shown by laboratory experiments (Jung and Pfänder 2007 and references therein).

Granitoids of the Weinsberg suite display the highest $\mathrm{CaO} / \mathrm{Na}_{2} \mathrm{O}$ ratios, especially the $\mathrm{Wbg} \mathrm{I}$ facies (0.48-0.98) (Fig. 6). All these granitoids were probably derived from metagreywackes, metagranites and/ or melt of a metagreywackes-metabasites mixture. Two-mica granites of the Eisgarn suite display distinctly lower $\mathrm{CaO} / \mathrm{Na}_{2} \mathrm{O}$ ratios $(0.10-0.48)$; most of them (Mrákotín and Deštná varieties) display $\mathrm{CaO} /$ $\mathrm{Na}_{2} \mathrm{O}<0.3$ (Fig. 7). Therefore, potential protolith of two-mica granites had very probably metapelitic composition. Melting of metagreywackes could have produced granites and granodiorites of the Freistadt suite with $\mathrm{CaO} / \mathrm{Na}_{2} \mathrm{O}$ ratios of 0.47 to 1.04 (Fig. 8). 

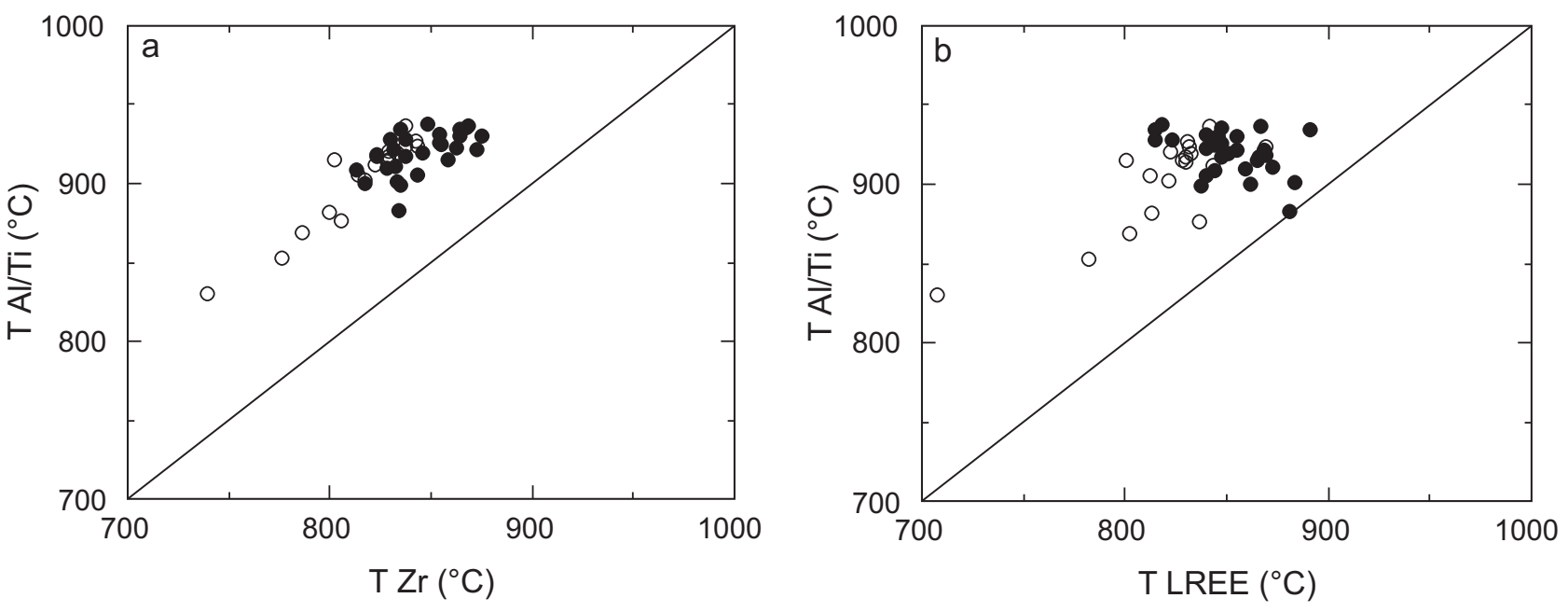

\section{- Weinsberg I O Weinsberg II}

Fig. 13a - Plot of $\mathrm{Al}_{2} \mathrm{O}_{3} / \mathrm{TiO}_{2}$ temperature estimates vs. zircon saturation temperatures for the Weinsberg suite; $\mathbf{b}-\mathrm{Plot}_{\text {of }} \mathrm{Al}_{2} \mathrm{O}_{3} / \mathrm{TiO}_{2}$ temperature estimates vs. LREE (monazite) saturation temperature for the Weinsberg suite.

According to this partly elevated ratio granodiorites of the Freistadt suite could be also derived from tonalitic and/or metabasaltic sources.

\section{4. $\mathrm{CaO} /\left(\mathrm{FeO}+\mathrm{MgO}+\mathrm{TiO}_{2}\right)$ as an index of source composition}

For subaluminous to weakly peraluminous granites and granodiorites some other major elements ratios, such as $\left(\mathrm{Na}_{2} \mathrm{O}+\mathrm{K}_{2} \mathrm{O}\right) /\left(\mathrm{FeO}+\mathrm{MgO}+\mathrm{TiO}_{2}\right)$ or $\mathrm{CaO} /(\mathrm{FeO}+$ $\mathrm{MgO}+\mathrm{TiO}_{2}$ ), are useful indices for source composition (Patiño Douce 1999). Both ratios can help distinguish between felsic or mafic metapelite and metagreywacke sources.

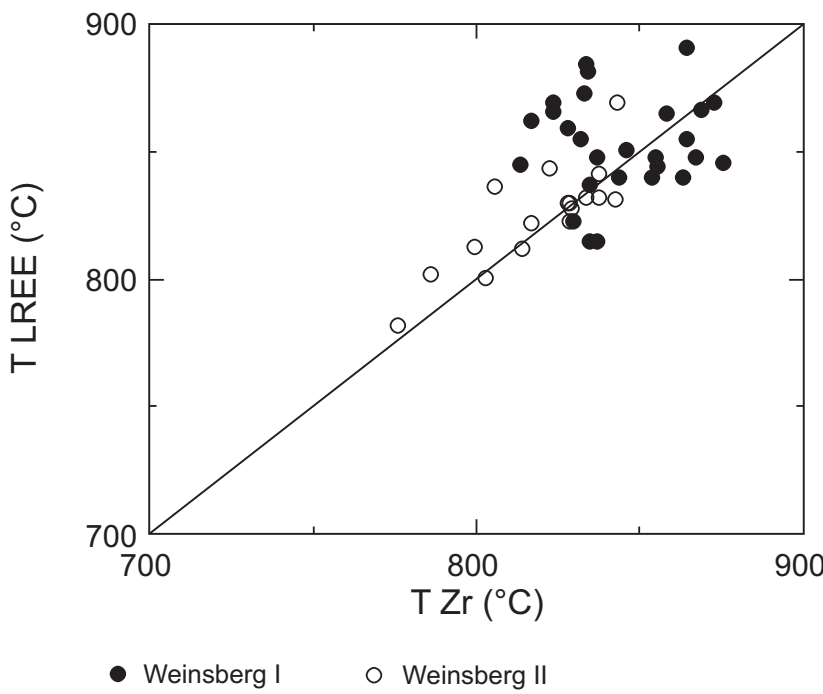

Fig. 14 Plot of LREE saturation temperature vs. zircon saturation temperature for the Weinsberg suite.
According to the $\mathrm{CaO} /\left(\mathrm{FeO}+\mathrm{MgO}+\mathrm{TiO}_{2}\right)$ ratio $(0.31-$ 0.58 ) the parental magma of the Weinsberg suite could have been produced by hybridization of high-Al olivine tholeiite melt with metagreywackes and metapelites (Fig. 9). According to this ratio the majority of two-mica granites of the Eisgarn suite were probably derived by melting of metapelites and metagreywackes (Fig. 10). In particular, the $\mathrm{CaO} /\left(\mathrm{FeO}+\mathrm{MgO}+\mathrm{TiO}_{2}\right)$ ratios for the Deštná granites $(0.24$ to 1.97$)$ require mainly felsic metapelites in the source. The two-mica granites of the Lipnice/Steinberg variety may have been derived by melting of metagreywackes (Fig. 10). The granites and granodiorites of the Freistadt suite $\left(\mathrm{CaO} /\left(\mathrm{FeO}+\mathrm{MgO}+\mathrm{TiO}_{2}\right)=0.49-0.97\right)$ could have been again generated by hybridization of tholeiitic melts with metagreywackes (Fig. 11).

\section{5. $\mathrm{Al}_{2} \mathrm{O}_{3} / \mathrm{TiO}_{2}$ ratio as a geothermometer}

Experimental results suggest that $\mathrm{Al}_{2} \mathrm{O}_{3} / \mathrm{TiO}_{2}$ ratios can be used to constrain the melting temperatures of granitoids (Sylvester 1998; Jung and Pfänder 2007). During partial melting of metapelites and metagreywackes, concentrations of $\mathrm{Al}_{2} \mathrm{O}_{3}$ in the melt remain constant, due to buffering by aluminous minerals (plagioclase, garnet, cordierite or $\mathrm{Al}_{2} \mathrm{SiO}_{5}$ ). In contrast, the $\mathrm{TiO}_{2}$ concentration increases with increasing temperature, probably due to the progressive breakdown of biotite or ilmenite at higher temperatures (Sylvester 1998). As shown in Fig. $12, \mathrm{Al}_{2} \mathrm{O}_{3} / \mathrm{TiO}_{2}$ vs. $\mathrm{CaO}$ concentrations are controlled by content of plagioclases, whereas concentrations of $\mathrm{TiO}_{2}$ in S-type granites may be, to a large extent, driven by accumulation of ilmenite. However, in I-type and I/S-type granites $\mathrm{Al}_{2} \mathrm{O}_{3} / \mathrm{TiO}_{2}$ ratios and $\mathrm{TiO}_{2}$ concentrations are also controlled by occurrence of titanite. 

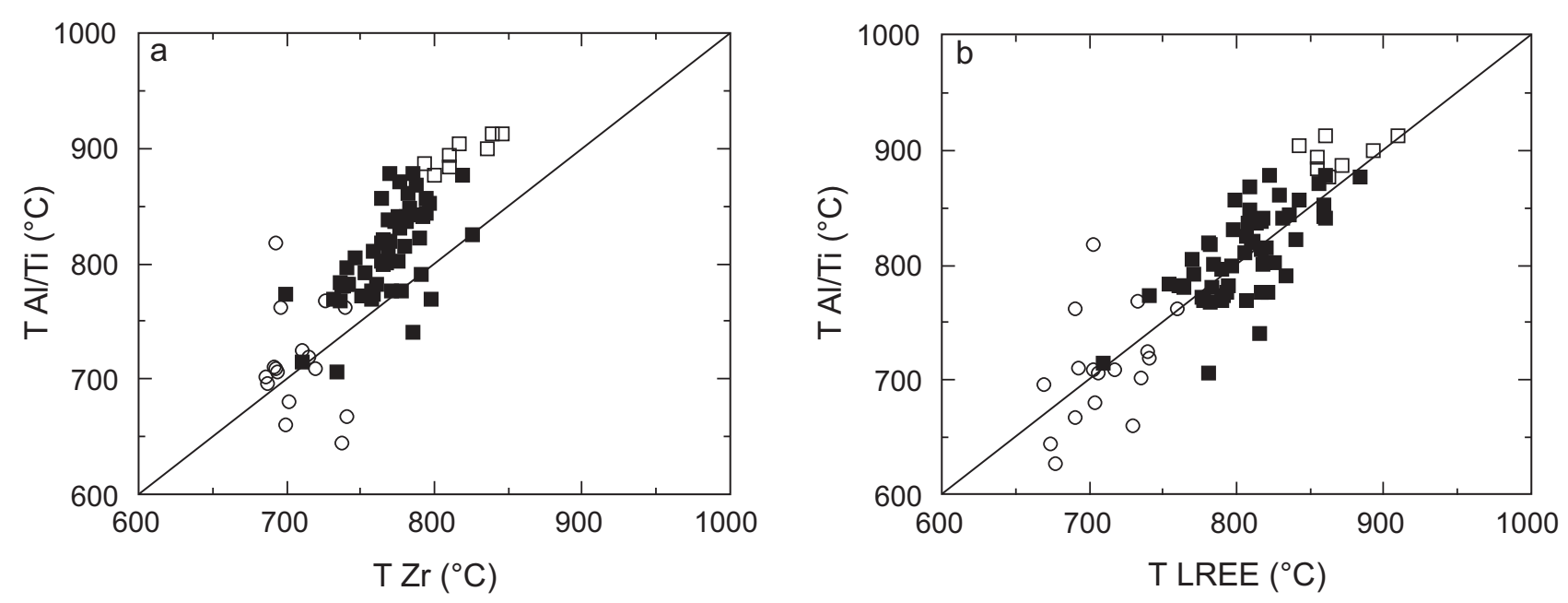

- Deštná granite — Mrákotín/Číměř granite $\square$ Lipnice/Steinberg granite

Fig. 15a - Plot of $\mathrm{Al}_{2} \mathrm{O}_{3} / \mathrm{TiO}_{2}$ temperature estimates vs. zircon saturation temperature for the Eisgarn suite; $\mathbf{b}-\mathrm{Plot}_{\text {of }} \mathrm{Al}_{2} \mathrm{O}_{3} / \mathrm{TiO}_{2}$ temperature estimates vs. LREE saturation temperature for the Eisgarn suite.

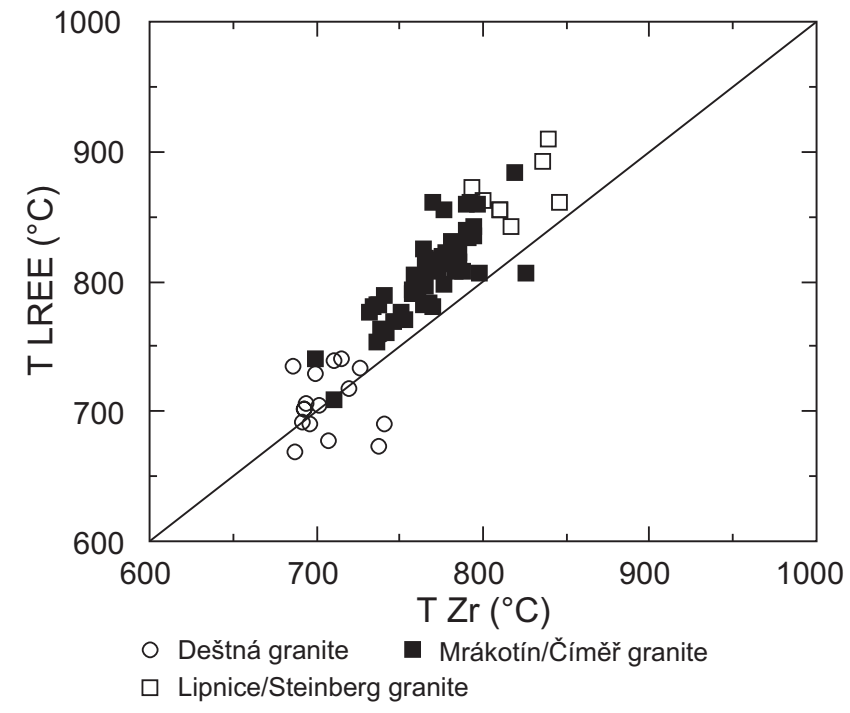

Fig. 16 Plot of LREE saturation temperature vs. zircon saturation temperature for the Eisgarn granite suite.

Using the good correlation between $\mathrm{Al}_{2} \mathrm{O}_{3} / \mathrm{TiO}_{2}$ ratios and temperatures of partial melts derived from different source rocks, 18 quantitative thermometric expressions were calculated by Jung and Pfänder (2007), utilizing different regression methods (power law, exponential law, linear regression) for pelite, psammite, amphibolites and igneous rock melting. All these expressions were tested for all granite varieties of the MB. The best agreement with the temperatures calculated using conventional accessory mineral saturation thermometry (Watson and Harrison 1983; Montel 1993) was obtained by using the exponential regression method for psammite melting $\left(\mathrm{T}^{\circ} \mathrm{C}=\left[\ln (23400)-\ln \left(\mathrm{Al}_{2} \mathrm{O}_{3} /\right.\right.\right.$ $\left.\left.\mathrm{TiO}_{2}\right)\right] / 0.00729$ ).

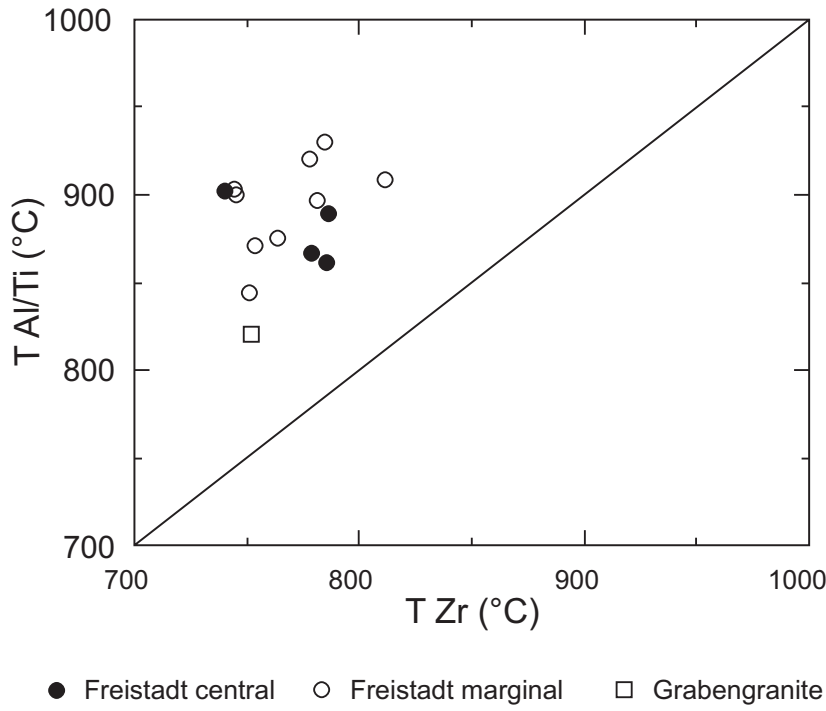

Fig. 17 Plot of $\mathrm{Al}_{2} \mathrm{O}_{3} / \mathrm{TiO}_{2}$ temperature estimates vs. zircon saturation temperature for the Freistadt suite.

In regard of potential metapelitic protolith of two-mica granites of the Eisgarn suite were also tested $\mathrm{Al}_{2} \mathrm{O}_{3} / \mathrm{TiO}_{2}$ temperature equations for pelite melting. However, these equations display distinctly higher, very probably unrealistic melting temperatures.

For the Weinsberg suite, the temperatures calculated from $\mathrm{Al}_{2} \mathrm{O}_{3} / \mathrm{TiO}_{2}$ ratios are $830-938^{\circ} \mathrm{C}$, and thus $c .20$ $100^{\circ} \mathrm{C}$ higher than both saturation temperatures (Fig. 13). The saturation temperatures are mutually comparable; however, some differences are observed that may be explained by the presence of inherited zircon or monazite grains (Fig. 14).

Comparison of temperatures calculated from $\mathrm{Al}_{2} \mathrm{O}_{3} /$ $\mathrm{TiO}_{2}$ ratios and saturation models for granitoids of the 


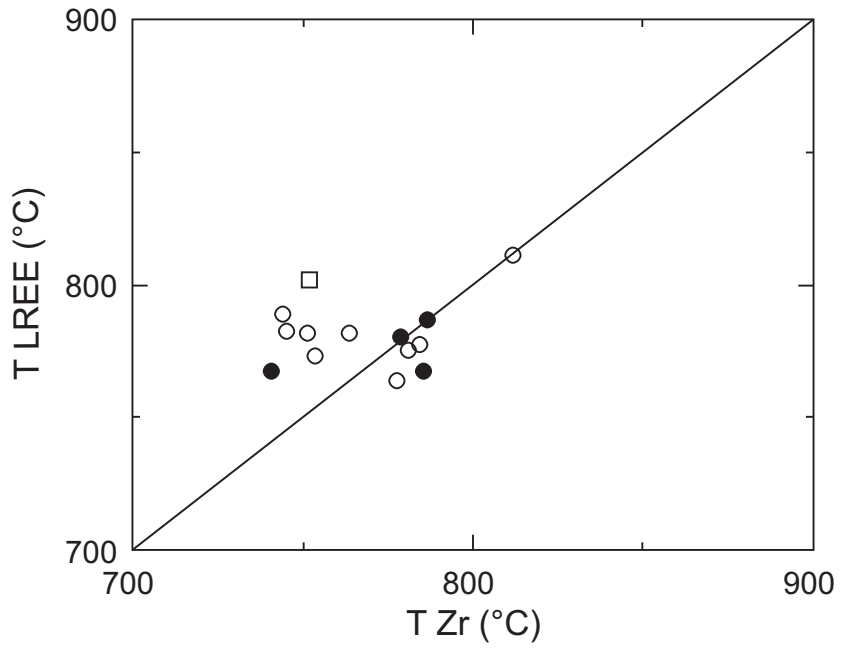

- Freistadt central $\bigcirc$ Freistadt marginal $\square$ Grabengranite

Fig. 18 Plot of LREE saturation temperature vs. zircon saturation temperature for the Freistadt suite.

Eisgarn suite paints another picture. The lowest melting temperatures were found for the Deštná granites (627$763^{\circ} \mathrm{C}$ ), and the highest for the Lipnice/Steinberg granites-granodiorites $\left(884-913^{\circ} \mathrm{C}\right)$. They are thus 4 to $67^{\circ} \mathrm{C}$ higher than the zircon saturation temperatures (Fig. 15). The highest difference is seen in the Lipnice/Steinberg granites, which display the lowest $\mathrm{Al}_{2} \mathrm{O}_{3} / \mathrm{TiO}_{2}$ ratios but the highest $\mathrm{TiO}_{2}$ concentrations (up to 0.5 wt. \%). Saturation temperatures for zircon are usually 3 to $64{ }^{\circ} \mathrm{C}$ lower than the LREE saturation temperatures (Fig. 16).

The temperature range for Freistadt biotite granodiorite calculated from the $\mathrm{Al}_{2} \mathrm{O}_{3} / \mathrm{TiO}_{2}$ ratios is $820-930^{\circ} \mathrm{C}$, and thus $59-118^{\circ} \mathrm{C}$ higher than the zircon saturation temperatures (Fig. 17). The LREE saturation temperatures are partly higher than the zircon-based ones (Fig. 18).

\section{Discussion}

In the past, the origin of granitoids from the Moldanubian Batholith was discussed using source modelling based on trace-element distribution (Vellmer and Wedepohl 1994; Siebel et al. 2008), Sr-Nd isotope compositions (Liew et al. 1989; Vellmer and Wedepohl 1994; Finger and Clemens 1995; Matějka and Janoušek 1998; Gerdes 2001) and experimental stability of biotite (René et al. 2008). All these studies concluded that granitoids of Moldanubian Batholith were generated by LP-HT partial melting of metasedimentary sources (especially granites of the Eisgarn suite; Vellmer and Wedepohl 1994; René et al. 2008) and/or by melting of a mixture of metasediments and amphibolites (e.g., Weinsberg suite; Gerdes 2001). The majority of these studies presumed that the granitic magmas further evolved by often significant fraction- ational crystallization, (e.g., Matějka and Janoušek 1998; Breiter 2010; Žák et al. 2011).

The use of major-element data, especially $\mathrm{CaO} /$ $\mathrm{Na}_{2} \mathrm{O}$ and/or $\mathrm{CaO} /\left(\mathrm{FeO}+\mathrm{MgO}+\mathrm{TiO}_{2}\right)$ ratios, for distinguishing source rocks of granitic melts was largely discussed by Patiño Douce (1995, 1999), Sylvester (1998) and Jung and Pfänder (2007). These studies, based on extensive databases of melting experiments (e.g., Patiño Douce 1999), showed that the $\mathrm{CaO} / \mathrm{Na}_{2} \mathrm{O}$ ratio is suitable for source rock estimation in the case of peraluminous granites (Sylvester 1998), whereas the $\mathrm{CaO} /\left(\mathrm{FeO}+\mathrm{MgO}+\mathrm{TiO}_{2}\right)$ ratio can be used for both peraluminous and metaluminous felsic compositions (Patiño Douce 1995, 1999). Melts with high $\mathrm{CaO} /$ $\mathrm{Na}_{2} \mathrm{O}$ ratios are generally interpreted as being derived from orthogneisses and/or amphibolites, rather than metagreywackes (e.g., Miller 1985; Sylvester 1998; Jung and Pfänder 2007).

The estimation of melting temperatures of granitic melts is often based on conventional saturation thermometers (Watson 1979; Watson and Harrison 1983; Montel 1993). However, especially in granitic rocks with abundant inherited zircon, the zircon saturation temperatures need to be interpreted with caution (Miller et al. 2003). In the case of the $\mathrm{MB}$, these conventional thermometers were used for estimating melting temperatures of the Weinsberg (Gerdes 1997) and Eisgarn (Gerdes 1997; René et al. 2008) suites.

The systematic positive shift of $\mathrm{Al}_{2} \mathrm{O}_{3} / \mathrm{TiO}_{2}$ temperatures in comparison with conventional saturation thermometers was explained by Jung and Pfänder (2007) through disequilibrium partial melting, during which some zircon and monazite were left in the source region. On the other hand, such differences found in all granite suites of the MB may be better accounted for by accumulation of ilmenite in the S-type granites, joined by titanite in the I- and I/S-type granites. Consequently, use of the $\mathrm{Al}_{2} \mathrm{O}_{3} / \mathrm{TiO}_{2}$ ratios for determination of granite melting temperatures can be questionable, especially in the fractionated I- and I/S-type granites.

\section{Conclusions}

This study of $\mathrm{CaO} / \mathrm{Na}_{2} \mathrm{O}$ and $\mathrm{Al}_{2} \mathrm{O}_{3} / \mathrm{TiO}_{2}$ ratios in three main magmatic suites of the Moldanubian Batholith (BM; Bohemian Massif) showed that both ratios might be, with some caution, used to constrain possible source rocks and melting temperatures. The melt of the Weinsberg suite was probably generated by partial melting of a metagreywackes-metabasalts mixture at c. $740-940^{\circ} \mathrm{C}$. According to the $\mathrm{CaO} /\left(\mathrm{FeO}+\mathrm{MgO}+\mathrm{TiO}_{2}\right)$ ratios, the majority of two-mica granites (Mrákotín/Číměř varieties) were generated by melting of metapelites at $770-825^{\circ} \mathrm{C}$. Melting 
of felsic metapelites probably generated Deštná leucogranites, whereas melting of metagreywackes could have produced the Lipnice/Steinberg granites. The systematic positive shift of $\mathrm{Al}_{2} \mathrm{O}_{3} / \mathrm{TiO}_{2}$ temperatures compared with zircon and monazite saturation temperatures in some S-type granites (Mrákotín/Číměř and Lipnice/Steinberg varieties) of the $\mathrm{MB}$ (up to $\sim 70^{\circ} \mathrm{C}$ ) can be explained by ilmenite accumulation. In I- and I/S-type granites of the $\mathrm{MB}$, the distinctly higher difference between both approaches (up to $\sim+120^{\circ} \mathrm{C}$ ) may be explained by ilmenite accumulation and/or by the appearance of titanite.

Acknowledgements. The work was carried out thanks to the support of the long-term conceptual development research organisation grant RVO 67985891 and Austrian Science Fund (FWF) project No. I1993. I wish also to thank A. Szameitat for her constructive remarks and English correction and both reviewers (D. Buriánek and I. Petrík) for their perceptive reviews of the manuscript, valuable comments and recommendations. I am also indebted to handling editor J. Žák and editor in-chief V. Janoušek for their valuable recommendations and careful editing of the last manuscript version.

Electronic supplementary material. The sample locations and whole-rock geochemical data for the newly analysed samples are available online at the Journal web site (http://dx.doi.org/10.3190/jgeosci.223).

\section{References}

Boynton WV (1984) Geochemistry of the rare earth elements: meteorite studies. In: HENDERSON P (ed) Rare Earth Element Geochemistry. Elsevier, Amsterdam, pp 63-114

Brandmayr M, Dallmeyer RD, Handler R, Wallbrecher E (1995) Conjugate shear zones in the Southern Bohemian Massif (Austria): implications for Variscan and Alpine tectonothermal activity. Tectonophysics 248: 97-116

Brandmayr M, Loizenbauer J, Wallbrecher E (1999) Contrasting P-T conditions during conjugate shear zone development in the Southern Bohemian Massif, Austria. Mitt Österr Geol Ges 90: 11-29

BREITER K (2010) Geochemical classification of Variscan granitoids in the Moldanubicum (Czech Republic, Austria). Abh Geol B-A 65: 19-25

Breiter K, Koller F (1999) Two-mica granites in the central part of the South Bohemian Pluton. Abh Geol B-A 56: 201-212

BÜTTNER SH (2007) Late Variscan stress-field rotation initiating escape tectonics in the south-western Bohemian Massif: a far field response to late-orogenic extension. J Geosci 52: 29-43
Chappell BW, Hine R (2006) The Cornubian Batholith: an example of magmatic fractionation on a crustal scale. Res Geol 56: 203-244

Clemens JD (2003) S-type granitic magmas - petrogenetic issues, models and evidence. Earth Sci Rev 61: 1-18

Condie KC (1993) Chemical composition and evolution of the upper continental crust, contrasting results from surface samples and shales. Chem Geol 104: 1-37

Finger F, Clemens J (1995) Migmatization and "secondary" granitic magmas: effects of emplacement and crystallization of "primary" granitoids in southern Bohemian Massif, Austria. Contrib Mineral Petrol 120: 311-326

Finger F, Roberts MP, Haunschmid B, Schermaier A, SteyRER HP (1997) Variscan granitoids of central Europe: their typology, potential sources and tectonothermal relations. Mineral Petrol 61: 67-96

Finger F, Gerdes A, René M, Riegler G (2009) The SaxoDanubian granite belt: magmatic response to postcollisional delamination of mantle lithosphere below the south-western sector of the Bohemian Massif (Variscan Orogen). Geol Carpath 60: 205-212

FRASL G, FINGER F (1988) Führer zur Exkursion der Österreichischen Geologischen Gesellschaft ins Mühlviertel und in den Sauwald am 22. und 23. September 1988. Exkursionsführer Österr Geol Ges 8: 1-29

FriedL G (1990) Geologisch-petrographische Untersuchungen in der Gegend nordöstlich von Freistadt (Oberösterreich) mit besonderer Berücksichtigung des „Grabengranits“. Unpublished MSc. thesis, University of Salzburg, pp 1-242

Fuchs G (1964) Exkursion III/4: Kristallin Mühlviertel und Sauwald, südliche Böhmische Masse. Mitt Geol Gesell 57: $281-289$

GerDEs A (1997) Geochemische und thermische Modelle zur Frage der spätorogenen Granitgenese am Beispiel des Südböhmischen Batholiths: Basaltisches Underplating oder Krustenstapelung? Unpublished $\mathrm{PhD}$. thesis, University of Göttingen, pp 1-113

Gerdes A (2001) Magma homogenisation during anatexis, ascent and/or emplacement? Constraints from the Variscan Weinsberg Granites. Terra Nova 13: 305-312

Gerdes A, Wörner G, Henk A (2000) Post-collisional granite generation and HT-LP metamorphism by radiogenic heating: the Variscan South Bohemian Batholith. J Geol Soc, London 157: 577-587

Gerdes A, Friedl G, Parrish RR, Finger F (2003) Highresolution geochronology of Variscan granite emplacement - the South Bohemian Batholith. J Czech Geol Soc 48: 53-54

Guillot S, Le Fort P (1995) Geochemical constraints on the bimodal origin of High Himalayan leucogranites. Lithos 35: 221-234

Holub F, KlečKa M, MatěJKa D (1995) VII.C.3 Moldanubian Zone. Igneous activity. In: Dallmeyer RD, Franke 
W, Weber K (eds) Pre-Permian geology of Central and Eastern Europe. Springer, Berlin, pp 444-452

Janoušek V, Moyen JF, Martin H, Erban V, Farrow C (2016) Geochemical Modelling of Igneous Processes - Principles and Recipes in $\mathrm{R}$ language. Bringing the Power of R to a Geochemical Community. Springer Verlag, Berlin, pp 1-346

JUNG S, PFÄNDER JA (2007) Source composition and melting temperatures of orogenic granitoids: constraints from $\mathrm{CaO} / \mathrm{Na}_{2} \mathrm{O}, \mathrm{Al}_{2} \mathrm{O}_{3} / \mathrm{TiO}_{2}$ and accessory mineral saturation thermometry. Eur J Mineral 19: 859-870

Kleč́k M, MatěJKa D, Jalovec J, VañKová V (1991) Geochemical investigation of the Eisgarn type granitoids in the southern part of Central Massif of the Moldanubian Pluton. Zpr Geol Výzk v r 1989: 109-111 (in Czech)

KlötZli US, PARRISh RR (1996) Zircon U/Pb and Pb/Pb geochronology of the Rastenberg granodiorite, South Bohemian Massif, Austria. Mineral Petrol 58: 19-21

Kцов H (1971) Der Freistädter Granodiorit im österreichischen Moldanubikum. Verh Geol B-A 1971/1: 98-142

KöHLER A (1931) Der Granit „Typus Eisgarn“ im nordwestlichen Waldviertel. Sitz-Ber Akad Wiss, math-naturwiss Kl 140: 847-861

Koutek J (1925) About granite from Mrákotín. Rozpr Čs Akad věd, II tř 34/18: 1-18 (in Czech)

Le Fort P, Cuney M, Deniel C, France-Lanord C, Sheppard SMF, UPRETI BN, VIDAL P (1987) Crustal generation of the Himalayan leucogranites. Tectonophysics 134:39-57

LiEw TC, Finger F, Höck V (1989) The Moldanubian granitoid plutons of Austria: chemical and isotopic studies bearing on their environmental setting. Chem Geol 78: 41-55

MATĚJKA D, JANOUŠEK V (1998) Whole-rock geochemistry and petrogenesis of granites from the northern part of the Moldanubian Batholith (Czech Republic). Acta Univ Carol, Geol 42: 73-79

Mattern F (2001) Permo-Silesian movements between Baltica and Western Europe: tectonics and "basin families". Terra Nova 13, 368-375

Miller CF (1985) Are strongly peraluminous magmas derived from pelitic sedimentary sources? J Geol 93: 673-689

Miller CF, McDowell SM, Mapes RW (2003) Hot and cold granites? Implications of zircon saturation temperatures and preservation of inheritance. Geology 31: 529-532

Montel JM (1993) A model for monazite/melt equilibrium and applications to the generation of granitic magmas. Chem Geol 110: 127-146

Отт WD (1988) Geologische Karte von Bayern 1:25 000. Erläuterungen zum Blatt Nr. 7149 Freyung und zum Blatt Nr. 7148 Bischofsreut. Bayrisches Geol Landesamt, München, pp 1-144

PatiÑo Douce AE (1995) Experimental generation of hybrid silicic melts by reaction of high-Al basalt with metamorphic rocks. J Geophys Res 100: 15623-15639
Patiño Douce AE (1999) What do experiments tell us about the relative contributions of crust and mantle to the origin of granitic magmas? In: CASTRO A, FERNÁNDEZ C, VigNERESSE JL (eds) Understanding Granites: Integrating New and Classical Techniques. Geological Society of London, Special Publications 168: 55-75

Pouchou JL, Pichoir F (1985) "PAP" $(\varphi-\rho-Z)$ procedure for improved quantitative microanalysis. In: ARMSTRONG JT (ed) Microbeam analysis. San Francisco Press, San Francisco, pp 104-106

RenÉ M (2003) Ti-rich granodiorite porphyries from the northeastern margin of the Klenov Massif(Moldanubian Zone of the Bohemian Massif). Acta Montana, Ser A, 23: 77-84

RenÉ M (2012) Two-mica granites of the Moldanubian batholith. Sbor Jihočes Muz v Čes Budějovicích, Přír Vědy 52: 5-25 (in Czech)

RenÉ M (2013) Muscovite-biotite granite from the Kalvárie hill in the Jihlava town. Geol Výzk Mor Slez 142-144 (in Czech)

René M, HáJek P (2010) Petrography and geochemistry of granitoids of the Strážný (Finsterau) granite body. Sbor Jihočes Muz v Čes Budějovicích, Přír Vědy 50: 51-57 (in Czech)

René M, HáJeK P (2011) Petrography and geochemistry of the Šumava Mts. granites. Sbor Jihočes Muz v Čes Budějovicích, Přír Vědy 51: 27-37 (in Czech)

René M, Holtz F, Luo Ch, Beermann O, Stelling J (2008) Biotite stability in peraluminous granitic melts: compositional dependence and application to the generation of two-mica granites in the South Bohemian Batholith (Bohemian Massif, Czech Republic). Lithos 102: 538-553

RICHARD LR (1995) MinPet: mineralogical and petrological data processing system, version 2.02. MinPet Geological Software. Québec, Canada

Siebel W, Shang CK, Reitter E, Rohrmüller J, Breiter K (2008) Two distinctive granite suites in the SW Bohemian Massif and their record of emplacement: constraints from geochemistry an zircon ${ }^{207} \mathrm{~Pb} / 206 \mathrm{~Pb}$ chronology. J Petrol 49: $1853-1872$

Sтӧвісн DM (1992) Trachtstudien und den akzessorischen Zirkonen des Weinsberger Granits im östlichen Mühlviertel und westlichen Waldviertel. Unpublished MSc. thesis, University of Salzburg, pp 1-59

SyLVESTER PJ (1998) Post-collisional strongly peraluminous granites. Lithos 45: 29-44

Vellmer C, Wedepohl KH (1994) Geochemical characterization and origin of granitoids from the South Bohemian Batholith in Lower Austria. Contrib Mineral Petrol 118: 13-32

Verner K, ŽÁ́ J, Nahodilová R, Holub FV (2008) Magmatic fabrics and emplacement of the core-sheet-bearing Knížecí Stolec durbachitic pluton (Moldanubian Unit, Bohemian Massif): implications for mid-crustal rework- 
ing of granulitic lower crust in the Central European Variscides. Int J Earth Sci 97: 19-33

Verner K, Žák J, Šrámek J, Paclíková J, ZavŘelová A, MACHeK M, Finger F, Johnson K (2014) Formation of elongated granite-migmatite domes as isostatic accommodation structures in collisional orogens. J Geodyn 73: $100-117$

Verner K, René M, ŽÁ́x J, JANoušeK V (2015) A brief introduction to the geology of the Moldanubian Batholith. In: JANOUŠEK V, ŽÁK J (eds) Eurogranites 2015: Variscan Plutons of the Bohemian Massif. Post-conference field trip following the $26^{\text {th }}$ IUGG General Assembly in Prague. Czech Geological Survey, Prague, pp 103-109

Watson EB (1979) Zircon saturation in felsic liquids: experimental results and applications to trace element geochemistry. Contrib Mineral Petrol 70: 407-419
WATSON EB, Harrison TM (1983) Zircon saturation revisited: temperature and composition effects in a variety of crustal magma types. Earth Planet Sci Lett 64: 295-304

Williamson BJ, Shaw A, Downes H, Thirlwall MF (1996) Geochemical constraints on the genesis of Hercynian two-mica leucogranites from the Massif Central, France. Chem Geol 127: 25-42

ZouBeK V (1949) Report on geological mapping on the sheet Jindřichův Hradec (sheet 4354). Věst Geol Úst ČSR 24: 193-195 (in Czech)

Žák J, Verner K, Finger F, Faryad SW, Chlupáčová M, VeselovskÝ F (2011) The generation of voluminous Stype granites in the Moldanubian unit, Bohemian Massif, by rapid isothermal exhumation of the metapelitic middle crust. Lithos 121: 25-40 